"Succession and corporate performance: the appropriate successor in family firms"

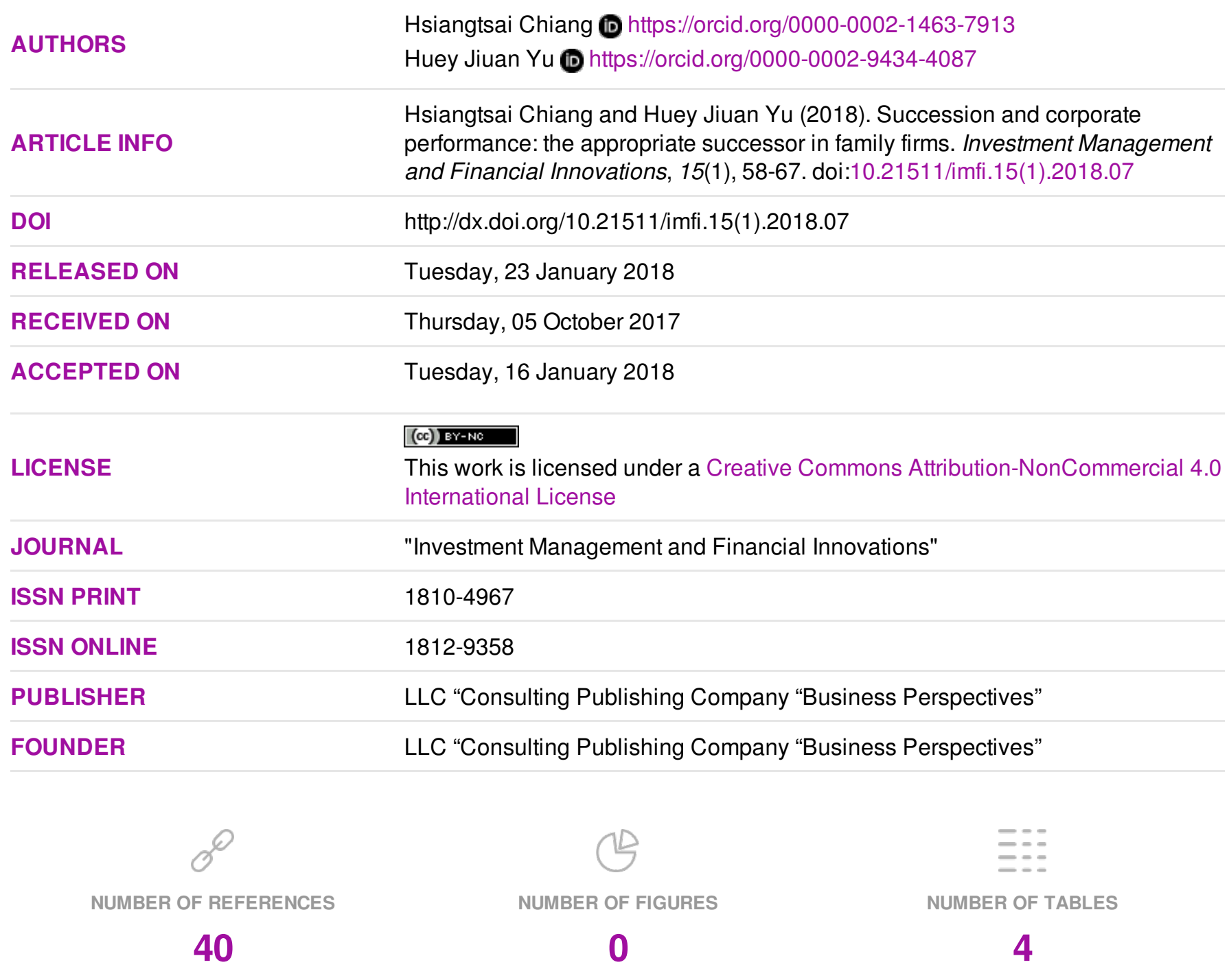

(C) The author(s) 2022. This publication is an open access article. 


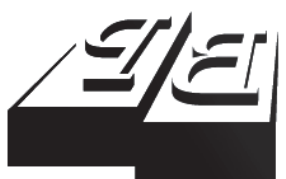

BUSINESS PERSPECTIVES

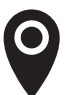

LLC "CPC "Business Perspectives" Hryhorii Skovoroda lane, 10, Sumy, 40022, Ukraine

www.businessperspectives.org

Received on: $5^{\text {th }}$ of October, 2017 Accepted on: $16^{\text {th }}$ of January, 2018

(C) Hsiangtsai Chiang,

Huey Jiuan Yu, 2018

Hsiangtsai Chiang, Professor, Department of Accounting, Feng Chia University, Taiwan.

Huey Jiuan Yu, Ph.D. Student, Doctoral Program of Business, Feng Chia University, Taiwan.

\title{
SUCCESSION AND CORPORATE PERFORMANCE: \\ THE APPROPRIATE SUCCESSOR IN FAMILY FIRMS
}

\begin{abstract}
Among the founders of family firms, succession is the greatest challenge to long-term success. According to The Family Firm Institute (n.d.), only about $30 \%$ of family businesses survive into the second generation, $12 \%$ are still viable into the third generation, and only about $3 \%$ of all family businesses operate into the fourth generation or beyond. In contrast to Western countries, the sustainable development of familyowned enterprises within Chinese society must rely on the operation of enterprises. Succession, being inevitable, can reduce the value of a company. This study sought to identify the appropriate succession plan to maintain business value and family's wealth. The main purpose of this study is to discuss the relationship between a family's succession, the successor, and firm performance. The sample is comprised of listed firms in Taiwan with necessary data from the Taiwan Economic Journal Database (TEJ). The period extends from 1996 till 2016. Securities, financial firms, and other elements of incomplete information are excluded from the sample. The research sample including 1,286 firms and 13,849 firm-year data, 2,918 of which indicate succession issues. This study employed regression model and investigated the relationships between family succession, the successor, and corporate performance. The main findings indicate that succession negatively influences corporate performance. However, an internal successor is better than an external one, and children successors are better than other relatives.
\end{abstract}

Keywords

JEL Classification succession, successor, family firm, corporate performance

G32, J24, L25

\section{INTRODUCTION}

According to the Liberty Times Net 2015 Chinese Family Firms Survey, the average age of a family firm in Taiwan is 30 years, the founder is 61 years old on average, $43 \%$ are succession enterprises, and the average tenure of the founder is 17.8 years, which is higher than that of China and Hong Kong. As a result, leaders of family firms in Taiwan are relatively older and face the problem of succession. Because of shareholding and stock dispersion within the family, conflicts related to succession arise. Recently, many founders of family firms in Taiwan have retired or passed away. Some enterprises, such as Formosa Plastics Group, have formed succession plans early on; others have experienced a series of conflicts after the founder passed away, e.g., Evergreen Group.

Succession involves a series of complex processes, influenced by family structure, transfer of wealth and power, change of management style, harmony of family members, different values and beliefs, and training, all of which affect corporate performance (Ghee, Ibrahim, \& Abdul-Halim, 2015). The literature on family firms and corporate performance research focuses mostly on comparing family and non- 
family benefits. Other studies compared family firm succession in terms of the founder, the second generation, the third generation, and so on, but no consistent results were obtained. This study focuses on management succession in which the successor types will be categorized as children, external executives, and other relatives. The main findings are as follows: (1) succession negatively influences corporate performance, (2) internal succession is better than external succession, and children successors bring greater success than other relatives.

This study contributes to the family firm literature in several ways. First, previous studies have only discussed the relationships between family and non-family firms or generations of family successors. This study further studies the succession of family firms and its relationship with corporate performance. Second, scant literature has examined characteristics of the successor and their impact on corporate performance. By so doing, this study provides implications for the most appropriate successor regarding the success of the firm.

\section{LITERATURE REVIEW AND HYPOTHESES DEVELOPMENT}

\subsection{Game theory and succession}

Game theory focuses on how the game participant performs a strategic response to the actions of other participants. In recent years, game theory has been applied to family firm research (Burkart, Panunzi, \& Shleifer, 2003; Morck \& Yeung, 2004; Blumentritt, Mathews, \& Marchisio, 2013). Michael-Tsabari and Weiss (2015) applied game theory to family firms to explore the succession from founder to successor. Succession represents a dynamic process, from the preparation of the actual succession to the succession after a period of time, and involves many different participants (Morris, Williams, Allen, \& Avila, 1997). Previous studies (Blumentritt et al., 2013; Michael-Tsabari \& Weiss, 2015) have confirmed that having family members in the process of succession with contestants through a series of choices will indeed affect the results.

\subsection{Agency, stewardship theories, and succession}

Agency theory was first proposed by Jensen and Meckling (1976). With inconsistency among the principal and agent goals or interests, proxy problems arise. Because family ownership, management unity, and its interests and supervision are not necessary in this perspective, this approach is not widely used (Chrisman, Chua, \& Litz, 2004; Jensen \& Meckling, 1976; Fama \& Jensen, 1983). In recent years, many studies have explained behavior, governance, and family corporate performance using agency and stewardship theory (e.g., Corbetta \& Salvato, 2004; Schulze, Lubatkin, Dino, \& Buchholtz, 2001; Shukla, Carney, \& Gedajlovic, 2014; Villalonga \& Amit, 2006). Research has presented new principal agent conflicts, such as those stemming from the family and non-family shareholder relationship (Villalonga \& Amit, 2006). Moreover, research demonstrates that agency governance mechanisms, such as board of directors, incentive compensation plans, and monitoring activities, serve their theorized purpose within family firms (Anderson \& Reeb, 2004; Braun \& Sharma, 2007). However, due to non-economic goals and family involvement, the transition from agency theory to stewardship theory to analyze family firms (Davis, Schoorman, \& Donaldson, 1997; Donaldson \& Davis, 1991) predicted the corporate performance of family firms (Eddleston \& Kellermanns, 2007).

The theory of stewardship originated in the study of Davis et al. (1997) and posits that the management of self-interest and organizational conflicts of interest is based on stewardship spirit and the choice not to violate the overall interests of the organization. However, family involvement management will improve corporate performance (Charbel, Bouri, \& Georges, 2013; Hoffmann, Wulf, \& Stubner, 2016). When family members agree with the firm and have emotional links with the enterprise, consideration for the survival and development of enterprises and reduction of risk will be performed with a long-term perspective (Miller \& Breton-Miller, 2006; Sciascia \& Mazzola, 2008). 


\subsection{Definition of family firms and succession}

Most researchers who have defined a family firm have observed family members' board size, stock ownership, management and administrative rights, etc. In general, Western countries tend to use management or ownership of shares to define family firms; because of the dispersion of equity, the definition of family firms emphasizes family members as managers or major shareholders. Therefore, family members are major shareholders or managers, and their enterprises will be thought of as family firms (Claessens, Djankov, \& Lang, 2000). However, in Asian countries, when the founder of a company is a major shareholder, it is defined as a family firm. Recently, more scholars have referred to the work of Chrisman, Chua, and Sharma (2005) to define four core orientations: family ownership, family control, family member manager roles, and generation intervention (Miller \& Breton-Miller, 2006). Fan and Bennedsen (2015) define family firms among large listed companies as those in which family members are the major owners and hold more than $10 \%$ of equity, or in which the family has more than a nominal ownership of the management. From the perspective of control, the Taiwan Economic Journal (TEJ) related seats are subject to friendly seats. Membership of more than $50 \%$ will overestimate the real influence on the seats of control, such as control holding more than $10 \%$ of the definition of a family firm, in which the company's shareholding structure is not considered to be different. This will cause the bias to be the right of control.

In summary, in Asian countries, the definition of a family firm should also consider the family ownership, control of seats, and the degree of participation of family members. The study adopts the definition of a family firm by Fan and Bennedsen (2015) as an enterprise in which family members hold more than $10 \%$ of equity, excess holdings are higher than 0 , and there are more than two family members serving as directors, supervisors, and first-level directors.

In Chinese corporate culture, succession is significant. Successors not only inherit the estate of a corporation, but also the proverbial throne. However, it is difficult for family firms to build a succes- sion-planning program. For family firms' founders, succession is the greatest long-term challenge. According to The Family Firm Institute (n.d.), only about $30 \%$ of family and businesses survive into the second generation, $12 \%$ are still viable into the third generation, and only about $3 \%$ of all family businesses operate into the fourth generation or beyond.

Succession is the process of transferring the power of entrepreneurship to successors. On the premise of sustainable development, a successor should improve the structure of the company (Lansberg, 1988). According to Aronoff and Ward (1990), when a new leader of a family firm completely controls the whole company, this is referred to as successful succession (Longenecker \& Schoen, 1978). According to Fan, Wong, and Zhang (2012), a succession takes place when a family member is appointed to the position of chairman and the founder transfers control to the successor. In this study, we apply this definition of succession.

\subsection{Succession and corporate performance}

During the process of succession, the founders are focused mainly on corporate sustainable management, with concern for transforming and upgrading firm strategies. Compared to non-family firms, the founders of family firms particularly preferred internal succession. Molly, Laveren, and Deloof (2010) indicated that transfer from the first to the second generation may negatively influence the leverage of the company, but no evidence has been found that a family firm's profitability is affected by succession. However, Fan, Jian, and Yeh (2008), using a sample of 214 family firms' corporate performance in Taiwan, Hong Kong and Singapore, found that after eight years of CEO change, the average share price fell nearly $60 \%$. Bennedsen, Fan, Jian, and Yeh (2015) investigated the succession issues present in firms in Taiwan, Hong Kong, and Singapore from 1987 to 2005, and indicated that family firm succession can reduce the value of a firm. In the first five years after replacement of the chairman, cumulative abnormal compensation fell to $56 \%$, but then recovered slightly, which may be related to special assets in family firms (Fan et al., 2008). Bennedsen et al. (2015) suggested that, from 1987 to $2005,74 \%$ of issues that arose were related to 
family firm succession; from 1997 to 2012, this figure declined to $53 \%$. For this reason, the study hypothesizes the following:

\section{H1: Family corporate performance becomes poorer after succession.}

\subsection{Successors and corporate performance}

Familialism, cronyism, and authoritarianism are three constituent elements of Chinese family firms (Farh \& Cheng, 2000), thus emphasizing the importance of transferring power to the second generation. The founders of family firms prefer internal succession, especially that by the eldest son. According to Fan et al. (2015), about $65 \%$ of Asian family firms used internal succession, about $22 \%$ used external succession, and the others were sold.

Research has revealed that succession impacts corporate performance. Most enterprises are concerned about who should be the successor. Morck, Shleifer, and Vishny (1988) argued that external succession brings greater benefit than internal succession, because the descendants may not inherit all of the founders' leadership qualities. Other studies indicated that only founders can create greater firm value, not the descendants (Villalonga \& Amit, 2006; Smith \& Amoako-Adu, 1999; Bennedsen, Nielsen, Pérez-González, \& Wolfenzon, 2007).
Conversely, when an enterprise demonstrates competitive advantage and uniqueness, the founders prefer internal succession (Lee, Lim, \& Lim, 2003). Bennedsen et al. (2015) indicated that founders create special assets in family firms, so they prefer internal succession. To confirm corporate performance after succession, the study further subdivided the successors into children, external individuals, and other relatives. As mentioned above, the founders of family firms prefer internal succession, especially by the eldest son, due to the Chinese culture of cronyism. For this reason, the study hypothesizes hypothesize the following:

H2a: Succession by children will result in higher corporate performance.

H2b: Succession by external executives will result in lower corporate performance than succession by relatives.

\section{METHODS}

\subsection{Data}

The sample consists of firms listed in Taiwan with key data listed in the TEJ. The sample period extends from 1996 till 2016. Securities and financial firms and firms with incomplete information are excluded from the sample. These criteria result

Table 1. Descriptive statistics

\begin{tabular}{|c|c|c|c|c|c|c|}
\hline \multirow{2}{*}{ Variable } & \multicolumn{3}{|c|}{ Family firms } & \multicolumn{3}{|c|}{ Succession } \\
\hline & $M$ & SD & $\mathbf{N}$ & $M$ & SD & $\mathbf{N}$ \\
\hline Tobin's Q & 1.3608 & 0.8368 & 13,849 & 1.2118 & 0.6217 & 2.918 \\
\hline EPS & 1.7610 & 4.0337 & 13,849 & 1.6531 & 6.1890 & 2.918 \\
\hline ROE & 0.0517 & 0.3416 & 13,849 & 0.0399 & 0.3345 & 2.918 \\
\hline Year & 28.3 & 12.653 & 13,849 & 36.6 & 12.057 & 2.918 \\
\hline S-Year & 1.22 & 8.473 & 13,849 & 1.22 & 8.473 & 2.918 \\
\hline Liv & 0.0765 & 0.0955 & 13,849 & 0.1018 & 0.1065 & 2.918 \\
\hline Size & 21.8986 & 1.3552 & 13,849 & 22.4788 & 1.5932 & 2.918 \\
\hline Board & 7.03 & 2.578 & 13,849 & 8.13 & 3.56 & 2.918 \\
\hline ID\% & 0.1557 & 0.1740 & 13,849 & 0.0729 & 0.1331 & 2.918 \\
\hline $\mathrm{CHI}$ & - & - & - & 0.73 & 0.442 & 2.143 \\
\hline CEO & - & - & - & 0.14 & 0.352 & 423 \\
\hline OR & - & - & - & 0.12 & 0.326 & 325 \\
\hline
\end{tabular}

Notes: performance: Tobin's $\mathrm{Q}=$ (common stock market price+ book value of the liabilities) / the book value of total assets, $\mathrm{EPS}=$ net income $/$ weighted average common shares, $\mathrm{ROE}=$ net income $/$ shareholder equity. Year $=$ the age of firms, S-Year $=$ succession year, Liv $=$ financial leverage, Size $=$ LN (market value), Board $=$ size of board, ID $\%=$ ratio of independent directors. Successor (SR): $\mathrm{CHI}=$ children, $\mathrm{CEO}=$ external executives, $\mathrm{OR}=$ other relatives 
in a final number of 13,849 examples from 1,286 family firms, of which 2,918 indicate succession issues. Table 1 presents the descriptive statistics and lists all variables of statistics. The average age of family firms without succession issues is 28.3 years, while the average age for those with succession issues was 36.6 years. According to the 2015 Chinese Family Firms Survey, the average tenure of the owners was 17.8 years. About $73 \%$ of the successors are children, and $12 \%$ succeed to other relatives. A total of $85 \%$ of firms demonstrate internal succession, which is higher than that of Fan et al. (2015). Their research shows that family firms in Taiwan are more inclined toward internal succession than other Asian countries.

\subsection{Dependent variable}

This study analyzed corporate performance according to market and accounting value regarding corporate performance. Market value is based on the approximate Tobin's Q calculated by Chung and Pruitt (1994) to measure corporate performance; Tobin's $Q$ is calculated using the market value of common stock and the book value of the liabilities divided by the book value of total assets. This study employ EPS and ROE as proxies for accounting for corporate performance, where EPS is calculated by net income divided by weighted average common shares, and ROE is calculated by net income divided by shareholder equity.

\subsection{Independent variable}

The main purpose of this study is to discuss the relationship among family succession, the successor, and corporate performance. Within this study, succession is discussed, excluding nonsuccession events, such as the operator to adjust the co-founder of the rotation between the family or the right to operate the main owner. The study also classifies successors into three categories: children, external executives, and other relatives.

\subsection{Control variables}

This study further includes some other determinants in corporate performance: age of the company, succession year, financial leverage, scale of the company, and corporate governance. The age of the company is the timeframe from the estab- lishment date to the present. Succession year is determined as when the leader retires from the position of chairman, and the family's second generation or external professional takes over the position. Succession years are defined as year 1 , year 2, etc. Financial leverage is the measured long-term liabilities divided by the book value of total assets. The scale of the company is calculated by the natural logarithm of the market value. Finally, corporate governance is measured in two ways: (1) the size of the board is measured as the proxy variable and (2) the ratio of the independent directors is measured independent of directors divided by whole directors.

\subsection{Empirical model}

This study discussed the relationship between succession, successor, and corporate performance. First, it identified the family firms with succession issues and classified them according to type of successors, then it examined the relationship between succession, successors, and corporate performance. The main purpose of this study is to identify the ideal successor. The following empirical model is proposed:

Performance $_{i t}=\beta_{0}+\beta_{1} \mathrm{Su}_{i t}+\beta_{2} \mathrm{Year}_{i t}+$
$+\beta_{3} \operatorname{Liv}_{, t}+\beta_{4} \operatorname{Size}_{i t}+\beta_{5}$ Board $_{, t}+\beta_{6} \mathrm{ID} \%_{i t}+\varepsilon_{i t}$.

Performance $_{i t}=\beta_{0}+\beta_{1}$ Children $_{i t}+\beta_{2} C E O_{i t}+$

$\beta_{3} O R_{i t}+\beta_{4} \mathrm{~S}-\mathrm{Year}_{i t}+\beta_{5}$ Year $_{i t}+\beta_{6} \operatorname{Liv}_{i t}+$

$+\beta_{7} \operatorname{Size}_{i t}+\beta_{8} \operatorname{Board}_{i t}+\beta_{9} \mathrm{ID}_{i t}+\varepsilon_{i t}$.

Model (1) discussed the relationship between succession of a family firm and corporate performance. It verifies Hypothesis 1, i.e., whether succession reduces business performance as advocated by most researchers (Fan et al., 2008; Bennedsen et al., 2015). In this study, Tobin's Q, EPS, and ROE are applied as proxy variables of corporate performance. Succession $(\mathrm{Su})$ is the independent variable. The age of company (Year), financial leverage (Liv), scale of company (Size), size of board (Board), and the ratio of the independent directors (ID\%) are the control variables, and $\varepsilon_{i t}$ is the model residual value. If $\beta_{1}$ is negative, then succession will reduce corporate performance. Model (2) discusses the relationship between successors and corporate performance and verifies Hypothesis 2a 
and Hypothesis $2 \mathrm{~b}$. To further examine the relationship between successors and corporate performance, this study rejoins the control variable of succession years (S-Year) and classifies successors into three categories: children, external executives (CEO), and other relatives (OR). According to Fan et al. (2015), about $65 \%$ of Asian family firms succeed to children. Regarding other relatives (OR), if $\beta_{1}$ is positive, which means succession by children will result in higher corporate performance, $\mathrm{H} 2 \mathrm{a}$ is supported. But if succession to children is not an option, this study explores whether other relatives or external executives (CEO) are better successors. Suppose $\mathrm{H} 2 \mathrm{a}$ is established; $\beta_{2}$ and $\beta_{3}$ should be negative, if the greater the weight, then relative corporate performance is poor.

\section{RESULT}

\subsection{Succession and corporate performance}

As mentioned above, family firms with succession issues reduce corporate performance. This study employed market and accounting value with corporate performance. The results of the regression equation validation from Model (1) are shown in Table 2. Table 2 is a regression analysis of performance and family succession, and it shows Tobin's Q, EPS, and ROE as dependent variables and succession $(\mathrm{Su})$ as an independent variable to test the correlation between succession and corporate performance. The empirical results show that succession decline corporate performance regarding both market and the ac- counting value, except in signification by ESP. Therefore, $\mathrm{H} 1$ is supported. With respect to the control variable, the age of the company, financial leverage and size of board have a significant negative impact on corporate performance, but the scale of the company and ratio of independent directors have a significant positive impact on corporate performance. The result shows that the larger scale of a company and the ratio of independent directors will improve corporate performance. Family firms can increase the proportion of independent directors to reduce the impact of succession.

\subsection{Successor and corporate performance}

Since the succession is inevitable and may reduce the value of the company, the family firms for the guardian of wealth must succeed to the appropriate successor. As mentioned previously, this study subdivided successors into children, external executives, and other relatives. The results of the regression equation validation from Model (2) are shown in Table 3. Table 3 is a regression analysis of successors and corporate performance; shows Tobin's Q, EPS, and ROE as dependent variables; and shows successors (children, external executives, and other relatives) as independent variables to test the correlation between the successor and corporate performance.

According to Tobin's Q, compared to children, if other relatives take over the company, then corporate performance will decline. Therefore, $\mathrm{H} 2 \mathrm{a}$ is supported. Compared to other relatives, if an exter-

Table 2. Regression analysis: performance and family succession

\begin{tabular}{|c|c|c|c|}
\hline & & $O \sigma^{\circ}$ & \\
\hline Perfo & $-\beta_{1} \mathrm{Su}_{i t}+$ & $+\beta_{4} \mathrm{Size}_{i t}$ & $\mathrm{O} \%_{i t}+\varepsilon_{i t}$. \\
\hline Variable & Tobin's Q & EPS & ROE \\
\hline Su & $-0.061^{* * *}$ & -0.102 & $-0.026^{* * *}$ \\
\hline Year & $-0.019 * * *$ & $-0.035^{* * *}$ & $-0.001^{* * *}$ \\
\hline Liv & $-1.608^{* * *}$ & $-7.092^{* * *}$ & $-0.384^{* * *}$ \\
\hline Size & $0.28^{* * *}$ & $1.377^{* * *}$ & $0.056^{* * *}$ \\
\hline Board & $-0.024^{* * *}$ & $-0.137^{* * *}$ & $-0.006^{* * *}$ \\
\hline ID\% & $0.057^{* * *}$ & $2.446^{* * *}$ & 0.009 \\
\hline
\end{tabular}

Notes: ${ }^{*} \mathrm{P}<.10 .{ }^{* *} \mathrm{P}<.05 .{ }^{* *} \mathrm{P}<.01$. Variable definitions are presented in Table 1. 
Table 3. Regression analysis: successor and corporate performance

\begin{tabular}{|c|c|c|c|c|c|c|}
\hline \multicolumn{7}{|c|}{$\begin{array}{l}\text { Model 2: } \\
\text { Performance }_{i t}=\beta_{0}+\beta_{1} \text { Children }_{i t}+\beta_{2} C E O_{i t}+\beta_{3} O R_{i t}+\beta_{4} \mathrm{~S}-\text { Year }_{i t}+\beta_{5} \text { Year }_{i t}+\beta_{6} \operatorname{Liv}_{i t}+\beta_{7} \text { Size }_{i t}+ \\
+\beta_{8} \text { Board }_{i t}+\beta_{9} \mathrm{ID}_{i t}+\varepsilon_{i t} .\end{array}$} \\
\hline \multirow{2}{*}{$\begin{array}{lr} & \text { Variable } \\
\mathrm{CHI} & \end{array}$} & \multicolumn{2}{|c|}{ Tobin's Q } & \multicolumn{2}{|c|}{ EPS } & \multicolumn{2}{|c|}{ ROE } \\
\hline & $0.052 *$ & - & $0.711^{* *}$ & - & -0.014 & - \\
\hline CEO & 0.023 & -0.028 & -0.253 & $-0.964^{* * *}$ & $-0.068^{* * *}$ & $-0.054^{* * *}$ \\
\hline OR & - & $-0.052^{*}$ & - & $-0.711^{* *}$ & - & 0.014 \\
\hline S-Year & $-0.011^{* * *}$ & $-0.011^{* * *}$ & -0.011 & -0.011 & $-0.003^{* * *}$ & $-0.003^{* * *}$ \\
\hline Year & $-0.011^{* * *}$ & $-0.011^{* * *}$ & $-0.04^{* * *}$ & $-0.04^{* * *}$ & 0.000 & 0.000 \\
\hline Liv & $-1.387^{* * *}$ & $-1.387^{* * *}$ & $-10.176^{* * *}$ & $-10.176^{* * *}$ & $-0.297^{* * *}$ & $-0.297^{* * *}$ \\
\hline Size & $0.211 * * *$ & $0.211^{* * *}$ & $1.637^{* * *}$ & $1.637^{* * *}$ & $0.039 * * *$ & $0.039 * * *$ \\
\hline Board & $-0.025^{* * *}$ & $-0.025^{* * *}$ & $-0.191^{* * *}$ & $-0.191^{* * *}$ & $-0.004^{*}$ & $-0.004^{*}$ \\
\hline ID\% & $0.368^{* * *}$ & $0.368^{* * *}$ & $2.617^{* * *}$ & $2.617^{* * *}$ & $0.141^{* * *}$ & $0.141^{* * *}$ \\
\hline
\end{tabular}

Notes: ${ }^{\star} \mathrm{P}<.10 .{ }^{* *} \mathrm{P}<.05 .{ }^{* \star *} \mathrm{P}<.01$. Variable definitions are presented in Table 1.

nal executive takes over the company, there will be a positive but insignificant impact on corporate performance, meaning that $\mathrm{H} 2 b$ is not supported.

According to EPS, compared to children, if external executives or other relatives take over the company, corporate performance will decline; such a disadvantage is greater with an external executive. This indicates that succession by children leads to higher corporate performance, thus supporting $\mathrm{H} 2 \mathrm{a}$. If external executives take over the company instead of other relatives, the firm will experience a higher but insignificant negative impact on corporate performance, meaning that $H 2 b$ is not supported.

In terms of ROE, compared to the succession by children, if external executives take over the company, the firm will experience a decline in corporate performance. Therefore, $\mathrm{H} 2 a$ is supported. If external executives take over the company rather than other relatives, corporate performance will decline. Therefore, $\mathrm{H} 2 b$ is supported.

With respect to the control variable, succession year, age of the company, financial leverage, and size of the board have a significant negative impact on corporate performance, but the scale of the company and ratio of independent directors have a significant positive impact on corporate performance. The empirical results are the same as succession and corporate performance. As mentioned above, succession year represents when the leader retires from the position of chairman, and the family's second generation or external professional takes over the position. Because succession results in a reduction of the company stock price or cumulative abnormal pay (Bennedsen et al., 2015), the greater number of years the successor takes over the position, the lower the correlation with corporate performance. Within this study, the average of succession time is 1.22 years. Compared to the corporations with succession issues, the average of succession time is 36.6 years. Thus, it is reasonable to note that number of years of succession has a significant negative impact on corporate performance.

In summary, regardless of the measure used, $\mathrm{H} 2 b$ is generally not supported. That means that, in comparison with succession to other relatives, succession to external executives may not result in a decline of corporate performance. In Chinese culture, founders generally want their children to take over the company; if they do not, succession by other relatives or external executives makes no practical difference, but the founder will tend to hand succession to other relatives. The results of the hypotheses are presented in Table 4.

Table 4. Results

\begin{tabular}{l|c:c:c}
\hline $\begin{array}{c}\text { Corporate } \\
\text { performance }\end{array}$ & Su (H1) & CHI (H2a) & OR (H2b) \\
\hline Tobin's Q & $\mathrm{Y}$ & $\mathrm{Y}$ & $\mathrm{N}$ \\
\hdashline $\mathrm{EPS}$ & $\mathrm{N}$ & $\mathrm{Y}$ & $\mathrm{N}$ \\
\hline ROE & $\mathrm{Y}$ & $\mathrm{Y}$ & $\mathrm{Y}$ \\
\hline
\end{tabular}

Notes: $\mathrm{Y}=$ Hypothesis is supported, $\mathrm{N}=$ Hypothesis is not supported. Variable definitions are presented in Table 1. 


\subsection{Robustness tests}

To assess the validity of the results, this study applied a robustness test that mainly relates to the use of alternative measures with respect to the analysis on corporate performance and succession, together with an assessment of the influence of successors on the results. ROA is calculated using net income divided by the book value of total assets. Corporations with high capital returns can stay in the corporation by earning a surplus to earn a high rate of return. In other words, ROA indicates the potential for growth. With regard to potential for growth, this study applies a further robustness check to explore succession and corporate performance by ROA. In correspondence with our previous findings, succession results in a decline of corporate performance, which confirms that $H 1$ is supported.

With the next robustness check, this study explores successor and corporate performance by ROA. Compared to succession by children, if an external executive or other relatives take over the company, an external executive will lead to a decline and other relatives will improve corporate performance, but this difference is insignificant. Compared to other relatives, if an external executive takes over the company, corporate performance will decline. That means that an internal successor will bring better results than an external successor. Despite the comparison to other relatives, children's succession will decline corporate performance, but this result doesn't affect the original empirical results.

\section{CONCLUSION AND LIMITATIONS}

In Chinese society, the family's wealth and business are linked together within the tradition of cronyism. However, succession is inevitable, and depending on who takes over the family firm, a firm can remain sustainable, and corporate performance can be enhanced. In particular, about $85 \%$ of family firms in Taiwan opt for internal succession. From Table 2, which presents the empirical results of the relation between succession and corporate performance, this study found that succession reduces corporate performance. Therefore, it is very important that a firm plan for the impact of succession in advance. Succession is a significant and inevitable event, and it is difficult to build a succession-planning program. However, the selection of an individual to take over the company succession can have an impact. Table 3 shows the empirical results of the relation between successor and corporate performance, and this study found that internal succession is better than external succession, and the succession of children is better than that of other relatives. However, not every suitable successor is willing to take over a firm. Therefore, family firms should be committed to finding and training successors to prepare for contingencies.

Succession often results in a reduction in the company's stock price or cumulative abnormal pay (Bennedsen et al., 2014). Furthermore, the longer the successor takes in assuming the position, the lower the correlation of the succession is with the corporate performance. Investors should thus choose corporations that have no succession issues, plan succession to their children, or plan for longer succession.

There are some limitations of this study. First, the sources of this study are TEJ and the Internet, which is a secondary source, so its authenticity and completeness cannot be assured. Second, although the data are confirmed by multiple parties, there remains the possibility that the study does not accurately measure the relationship between family members and corporate success in some firms. Where possible, future studies should strive to collect data from more complete databases. 


\section{REFERENCES}

1. Anderson, R. C., \& Reeb, D. M. (2004). Board composition: Balancing family influence in S\&P 500 firms. Administrative science quarterly, 49(2), 209-237. Retrieved from http://journals.sagepub.com/doi/abs/10.2307/4131472

2. Aronoff, C. E., \& Ward, J. L. (1990). Succession: A new image. Nation's Business, 78, 46.

3. Bennedsen, M., Fan, J. P., Jian, M., \& Yeh, Y. H. (2015). The family business map: Framework, selective survey, and evidence from Chinese family firm succession. Journal of Corporate Finance, 33, 212-226. Retrieved from https:// dr.ntu.edu.sg/bitstream/handle/10220/25342/Bennedsen $\% 20$ et\%20al\%20_2014_family_business_map.pdf?sequence $=1$

4. Bennedsen, M., Nielsen, K. M., Pérez-González, F., \& Wolfenzon, D. (2007). Inside the family firm: The role of families in succession decisions and performance. The Quarterly Journal of Economics, 122(2), 647-691. Retrieved from https://papers.ssrn.com/sol3/papers.cfm?abstract_id $=925650$

5. Blumentritt, T., Mathews, T., \& Marchisio, G. (2013). Game theory and family business succession: An introduction. Family Business Review, 26(1), 51-67. Retrieved from http://c.ymcdn. com/sites/www.ffi.org/resource/ resmgr/FFI_on_Friday/FBR_26Game_Theory_and_Famil.pdf

6. Braun, M., \& Sharma, A. (2007). Should the ceo also be chair of the board? An empirical examination of family-controlled public firms. Family Business Review, 20(2), 111-126.

7. Burkart, M., Panunzi, F., \& Shleifer, A. (2003). Family firms. The Journal of Finance, 58(5), 2167-2201.

8. Charbel, S., Elie, B., \& Georges, S. (2013). Impact of family involvement in ownership management and direction on financial performance of the Lebanese firms. International Strategic Management Review, 1(1), 30-41. https:// doi.org/10.1016/j.ism.2013.08.003
9. Chrisman, J. J., Chua, J. H., \& Litz, R. A. (2004). Comparing the agency costs of family and non-family firms: Conceptual issues and exploratory evidence. Entrepreneurship Theory and practice, 28(4), 335-354. Retrieved from https://s3.amazonaws.com/ academia.edu.documents/481 63943/j.1540-6520.2004.00049. x20160818-12808-1d5qsz9.pdf ?AWSAccessKeyId=AKIAIWO WYYGZ2Y53UL3A\&Expires=1514968523\&Signature $=$ GPmEi8a OnkUi70jt0zDiOE2JpMc\%3D\&re sponse-content-disposition=inline \%3B\%20filename\%3DComparing the_Agency_Costs_of_Family_and.pdf

10. Chrisman, J. J., Chua, J. H., \& Sharma, P. (2005). Trends and directions in thedevelopment of a strategic management theory of the family firm. Entrepreneurship theory and practice, 29(5), 555-576. Retrieved from http:// www.modir21.com/wp-content/ uploads/2010/04/fulltext2.pdf

11. Chung, K. H., \& Pruitt, S. W. (1994). A simple approximation of Tobin's q. Financial management, 70-74. Retrieved from http://www4.fe.uc.pt/ jasa/m_i_2010_2011/asimpleapproximationsoftobinsq.pdf

12. Claessens, S., Djankov, S., \& Lang, L. H. (2000). The separation of ownership and control in East Asian corporations. Journal of financial Economics, 58(1), 81-112. Retrieved from http://www.edegan.com/pdfs/ERBC/Schoar, $\% 20$ 5.27.11/Claessens_Djankov_ Lang_2000.pdf

13. Corbetta, G., \& Salvato, C. (2004). Self-serving or self-actualizing? Models of man and agency costs in different types of family firms: A commentary on "comparing the agency costs of family and non-family firms: Conceptual issues and exploratory evidence". Entrepreneurship Theory and Practice, 28(4), 355-362.

14. Davis, J. H., Schoorman, F. D., \& Donaldson, L. (1997). Toward a stewardship theory of management. Academy of Management review, 22(1), 20-47. Retrieved from https://www.uhu.es/alfonso_ vargas/archivos/stewardship $\% 20$ theory.pdf

15. Donaldson, L., \& Davis, J. H. (1991). Stewardship theory or agency theory: CEO governance and shareholder returns. Australian Journal of management, 16(1), 49-64. Retrieved from http:// faculty.wwu.edu/dunnc3/rprnts. stewardshiporagency.pdf

16. Eddleston, K. A., \& Kellermanns, F. W. (2007). Destructive and productive family relationships: A stewardship theory perspective. Journal of Business Venturing, 22(4), 545-565.

17. Fama, E. F., \& Jensen, M. C. (1983). Separation of ownership and control. The journal of law and Economics, 26(2), 301-325.

18. Family Firm Institute (n.d.). Succession Planning. Retrieved from https://www.familybusinessinstitute.com/consulting/successionplanning/

19. Fan, J. P., Jian, M., \& Yeh, Y. H. (2008). Succession: The roles of specialized assets and transfer costs. Retrieved from http://www. cuhk.edu.hk/ief/josephfan/doc/ research_working_paper/08.pdf

20. Fan, J. P., Wong, T. J., \& Zhang, T. (2012). Founder succession and accounting properties. Contemporary Accounting Research, 29(1), 283311. Retrieved from http://www. cuhk.edu.hk/ief/josephfan/doc/ research_published_paper/15.pdf

21. Fan, J. P., \& Bennedsen, M. (2015). The family business map. Taipei: Cite Publishing Ltd.

22. Farh, J. L., \& Cheng, B. S. (2000). A cultural analysis of paternalistic leadership in Chinese organizations. In Management and organizations in the Chinese context (pp. 84-127). Palgrave Macmillan UK.

23. Ghee, W. Y., Ibrahim, M. D., \& Abdul-Halim, H. (2015). Family business succession planning: unleashing the key factors of business performance. Asian 
Academy of Management Journal, 20(2). Retrieved from http:// web.usm.my/aamj/20022015/ aamj20022015_5.pdf

24. Hoffmann, C., Wulf, T., \& Stubner S. (2016). Understanding the performance consequences of family involvement in the top management team: The role of long-term orientation. International Small Business Journal, 34(3), 345-368. Retrieved from http://journals. sagepub.com/doi/abs/10.1177/026 6242614550500?journalCode=isbb

25. Jensen, M. C., \& Meckling, W. H. (1976). Theory of the firm: Managerial behavior, agency costs and ownership structure. Journal of financial economics, 3(4), 305-360.

26. Lansberg, I. (1988). The succession conspiracy. Family business review, 1(2), 119-143.

27. Lee, K. S., Lim, G. H., \& Lim, W. S. (2003). Family business succession: Appropriation risk and choice of successor. Academy of Management Review, 28(4), 657-666.

28. Liberty Times Net (2015). Family firms in Taiwan is difficult to succession. Retrieved from http:// news.ltn.com.tw/news/business/ breakingnews/1505655

29. Longenecker, J. G., \& Schoen, J. E. (1978). Management succession in the family business. Journal of
Small Business Management (pre1986), 16(000003), 1.

30. Michael-Tsabari, N., \& Weiss, D. (2015). Communication traps: Applying game theory to succession in family firms. Family Business Review, 28(1), 26-40. Retrieved from https://coller.tau.ac.il/sites/ nihul_en.tau.ac.il/files/RP_313_ Weiss_0.pdf

31. Miller, D., \& Breton-Miller, L. (2006). Family governance and corporate performance: Agency, stewardship, and capabilities. Family business review, 19(1), 73-87.

32. Molly, V., Laveren, E., \& Deloof, M. (2010). Family business succession and its impact on financial structure and performance. Family Business Review, 23(2), 131-147. Retrieved from http://c.ymcdn. com/sites/ffi.site-ym.com/resource/resmgr/fbr_most_popular/ fbr_molly_familybusinesssucc.pdf

33. Morck, R., \& Yeung, B. (2004). Family control and the rent-seeking society. Entrepreneurship Theory and Practice, 28(4), 391-409. Retrieved from https:// deepblue.lib.umich.edu/bitstream/ handle/2027.42/39971/wp585. pdf? sequence $=3 \&$ is Allowed $=y$

34. Morck, R., Shleifer, A., \& Vishny, R. W. (1988). Management ownership and market valuation: An empirical analysis. Journal of financial economics, 20, 293-315.
35. Morris, M. H., Williams, R. O., Allen, J. A., \& Avila, R. A. (1997). Correlates of success in family business transitions. Journal of business venturing, 12(5), 385-401.

36. Schulze, W. S., Lubatkin, M. H., Dino, R. N., \& Buchholtz, A. K. (2001). Agency relationships in family firms: Theory and evidence. Organization science, 12(2), 99-116.

37. Sciascia, S., \& Mazzola, P. (2008). Family involvement in ownership and management: Exploring nonlinear effects on performance. Family Business Review, 21(4), 331-345. Retrieved from https://c.ymcdn. com/sites/ffi.site-ym.com/resource/ resmgr/fbr_most_popular/fbr_ sciascia_familyinvolveme.pdf

38. Shukla, P. P., Carney, M., \& Gedajlovic, E. (2014). Economic theories of family firms. The Sage handbook of family business, 100-118.

39. Smith, B. F., \& Amoako-Adu, B. (1999). Management succession and financial performance of family controlled firms. Journal of Corporate Finance, 5(4), 341-368.

40. Villalonga, B., \& Amit, R. (2006). How do family ownership, control and management affect firm value? Journal of financial Economics, 80(2), 385-417. Retrieved from https://pdfs.semanticscholar. org/197f/64b33859f9e36d8779528 5f24e16e77b4502.pdf 